\title{
ASEAN and China: Export Rivals or Partners in Regional Growth?
}

\author{
David Roland Holst ${ }^{1}$ and John Weiss ${ }^{2}$ \\ ${ }^{1}$ University of California, Berkeley, and Rural Development Research Consortium, Berkeley, and \\ ${ }^{2}$ Asian Development Bank Institute and University of Bradford, UK
}

\section{INTRODUCTION}

( HINA'S initial opening to the world economy in the late 1980s followed by its relatively rapid trade liberalisation in the second half of the 1990s and its recent WTO accession has prompted extensive debate amongst the policy community in many countries. ${ }^{1}$ Governments of the ASEAN group in particular have been extremely concerned at the prospect of FDI diversion and the loss of export market share in OECD economies to China. This paper summarises detailed empirical research by the authors intended to strengthen the basis of evidence on the important issue of export rivalry. In particular, we seek to elucidate the underlying properties of comparative advantage and export competition in the countries concerned, synthesising detailed trade flow and econometric analysis. Our econometric results indicate that, in the short run at least, ASEAN and China are experiencing intensified export competition in prominent third markets such as Japan and the US. More extensive trade flow analysis reveals, however, that in the long run globalisation can accommodate export growth by all the economies of East Asia, if aggregate growth can be sustained to facilitate the structural adjustments necessary for an optimal regional division of labour.

More specifically, the path forward is not without potential rivalry, but wellinformed policy makers can anticipate emergent challenges and take the steps necessary to mitigate adjustment costs and promote longer-term efficiency. Whatever the ultimate course of development in East Asia, it is clear that the forces at work are complex and in many cases unprecedented. Policy makers relying on

The views expressed here are those of the authors and should not be attributed to their affiliated institutions. The authors acknowledge the comments of an anonymous referee.

${ }^{1}$ See APEC (1997) and OECD (1999) for a discussion. 
intuition alone are very unlikely to anticipate events accurately or respond with measures that approach optimality. For this reason, we strongly advocate more empirical work on this issue, and more intensive and extensive use of the methods applied here can improve visibility for policy makers elsewhere.

The first half of the paper examines East Asian regional trade data econometrically, while the second half applies more descriptive tools. In Section 2, very disaggregated trade data are examined to identify very specific conditions in China-ASEAN export competition. In particular, we present estimates of the extent to which the main ASEAN economies (the ASEAN 5) have lost market share to Chinese exports in the US and Japanese markets. We conclude there was indeed a substantial and widespread loss of export markets across the majority of product categories in the period 1995-2000. ${ }^{2}$ Furthermore, this loss tends to be greatest in the export activities in which ASEAN economies are most specialised, findings that confirm and sharpen current thinking on short-run loss of competitiveness to China. However, in the longer term there is considerable potential for complementarity between ASEAN and China. The modelling work in RolandHolst (2002) brings this out clearly, with projections of a rapid import growth by China that generates sustained current account surpluses for ASEAN economies in their trade with China.

Achieving such trade complementarity will require successful adjustment within ASEAN economies, and the second half of the paper focuses on these broader patterns of adjustment. Here we use trade flow analysis to elucidate more extensive regional patterns of export competitiveness and underlying comparative advantage. Our results summarise trade competitiveness conditions for China, Japan, Korea, Taipei China, ASEAN, the US and the EU, and we give general indications about trends over the 1996-2000 interval. Focusing on detailed bilateral trade conditions for China and ASEAN, a variety of interesting patterns emerge. As expected, China's economic emergence is giving rise to significant new regional export competition, but in these initial results we see more complementarity than direct tradeoffs with its neighbours. In particular, it appears that ASEAN may be holding its own in higher value-added exports, and that the new China market may represent a significant 'cushion' to crowding out of third-country export markets, like the US and Japan. Overall, these general structural results indicate that growth of the East Asian regional economy and its global export markets might be able to accommodate simultaneous expansion of Chinese and ASEAN export capacity. A final section of the paper offers concluding remarks.

\footnotetext{
2 The ASEAN 5 consists of Singapore, Malaysia, Thailand, Indonesia and the Philippines. In 1995 the US and Japan together took roughly 40 per cent of China's exports and about 35 per cent of the exports of the ASEAN 5. In this paper all trade data cited come from the UN (COMTRADE) database.
} 


\section{ECONOMETRIC ESTIMATES OF SHORT-TERM COMPETITION:}

ASEAN 5 AND CHINA

To establish the degree of loss in market share to Chinese exports, we apply a version of constant market share analysis. ${ }^{3}$ For a given country $j$ export growth for a given commodity $i$ to a particular market (e.g. US or Japan) can be decomposed into a share effect (assuming country $j$ keeps a constant share of the market) and a competitiveness effect (allowing for its changing market share). If a comparator economy (in this case China) is introduced competitiveness can in turn be decomposed into change in its market share relative to China and the change in China's market share relative to the rest of the world. Hence we have:

$$
\Delta X_{i j}=\Delta Q_{i} \cdot s_{i j}+s_{i j} \cdot Q_{i}^{*}\left(\Delta s_{i j} / s_{i j}-\Delta s_{i k} / s_{i k}\right)+\Delta s_{i k} / s_{i k} \cdot s_{i j} \cdot Q_{i}
$$

where $X$ is exports and $\Delta$ is the absolute change in, $Q_{i}$ is total imports of $i$ in the market concerned (at the end of the period), $s_{i j}$ is the initial market share of country $j$ in imports of $i$ and with competitor country $k, s_{i k}$ is $k$ 's market share for product $i$.

In expression (1) the second term gives a measure of competitiveness for country $i$ relative to the comparator and this is the measure that we estimate and explain for the ASEAN 5 and individual economies relative to China.

\section{a. Decomposition of Change in Exports from ASEAN 5 to the US and Japan, $1995-2000$}

We apply this approach to ASEAN exports to the US and Japan over the period 1995-2000 during which competition from Chinese exports has been increasing strongly in many product categories. To illustrate the magnitude of the loss of exports due to the loss of market share relative to China, Table 1 decomposes the change in exports 1995-2000 for the five two-digit SITC categories for which for the ASEAN 5 the absolute export loss relative to China in the US and Japanese markets is greatest. Change in exports in each category is set at 100 , so the competitiveness effect vis-à-vis China is a proportion of this.

\footnotetext{
${ }^{3}$ For a conceptual discussion, see Richardson (1971). The approach here uses a version of equation (6) from Richardson (1971). The analysis differs from a conventional constant market share approach as it looks separately at two markets (the US and Japan) and at different export categories. Hence the commodity composition and export composition effects, which are relevant when total exports to the world are the focus of attention, are not required here.
} 
TABLE 1

ASEAN Export Competitiveness: Decomposition for US Market (key SITC categories 1995-2000)

\begin{tabular}{|c|c|c|c|c|c|}
\hline SITC & $\begin{array}{l}\text { Export } \\
\text { Increase to US } \\
1995-2000\end{array}$ & $\begin{array}{l}\text { Constant } \\
\text { Market Share } \\
\text { Effect }\end{array}$ & $\begin{array}{l}\text { Overall } \\
\text { Competitiveness }^{\mathrm{a}}\end{array}$ & $\begin{array}{l}\text { Competitiveness } \\
\text { viz. China }\end{array}$ & $\begin{array}{l}\text { Export Growth } \\
\text { as a Per Cent of } \\
1995 \text { Exports }\end{array}$ \\
\hline \multicolumn{6}{|c|}{ US Market } \\
\hline 75 & 100 & 112 & -12 & -220 & 42 \\
\hline 77 & 100 & 82 & 18 & -126 & 55 \\
\hline 76 & 100 & 593 & -493 & -572 & 18 \\
\hline 89 & 100 & 574 & -474 & -674 & 10 \\
\hline 82 & 100 & 169 & -69 & -197 & 78 \\
\hline \multicolumn{6}{|c|}{ Japanese Market } \\
\hline 34 & 100 & 123 & -23 & -320 & 51 \\
\hline 75 & 100 & 127 & -27 & -192 & 55 \\
\hline 76 & 100 & 194 & -94 & -248 & 24 \\
\hline 3 & -100 & -46 & -54 & -127 & -26 \\
\hline 63 & -100 & -41 & -59 & -417 & -10 \\
\hline
\end{tabular}

Notes:

SITC 3 (Raw Fish), 34 (Natural Gas), 63 (Cork and Wood), 75 (Office and Automatic Data Processing Machines), 76 (Telecommunications), 77 (Electrical Machinery), 82 (Furniture), 89 (Miscellaneous).

${ }^{\text {a }}$ Sum of second and third terms in equation (1).

${ }^{\mathrm{b}}$ Second term in equation (1).

In all of these categories there has been a strong effect from the loss of market share relative to China, and in some categories the absolute value of the change in relative market share is several times the value of the actual export increase. For example, for office machines (SITC 75) in both the US and Japanese markets the loss of exports due to the falling market share relative to China is roughly double the actual export increase achieved, whilst for telecommunications (SITC 76) in the US it is nearly six times the actual increase. In many of these categories, however, this strong loss of market share was still accompanied by rising exports from ASEAN.

\section{b. Regression Analysis}

The analysis of changing competitiveness relative to China is extended by focusing on trends at the four-digit SITC level. We use as our measure of competitiveness, change in market share relative to China, which is the second term in equation (1), scaled by division by total exports in 1995 in the same category. Using the notation in equation (1), competitiveness (COMP) is measured as:

$$
\mathrm{COMP}_{i j}=\left[s_{i j} \cdot Q_{i}^{*}\left(\Delta s_{i j} / s_{i j}-\Delta s_{i k} / s_{i k}\right)\right] / X_{i j}
$$


where $X_{i j}$ is initial exports of $i$ from $j$ to the market concerned. Where there is a gain in market share relative to China, COMP will be positive and where there is a loss it will be negative. ${ }^{4}$

We test the following three hypotheses:

- loss of competitiveness is systematically related to the characteristics of trade categories, whether in terms of technological characteristics, or patterns of specialisation;

- loss of competitiveness differs systematically between countries in the ASEAN group;

- loss of competitiveness trends are similar between the US and Japanese markets.

To test these we utilise a simple model that makes competitiveness a function of the characteristics of products, general shifts in competitiveness and changes in tastes as a demand factor. As a measure of specialisation, we use the relative revealed comparative advantage measure (RCA) at the start of a period to explain changing competitiveness over this period. ${ }^{5}$ We use the initial relative RCA to explain change in competitiveness, on the grounds that the initial RCA can be taken as a proxy for the relative output level and factor intensity of different products. Full details of the theoretical model underlying the analysis are in Weiss and Gao (2002). ${ }^{6}$

In principle, RCA can be related to the change in competitiveness through two possible routes:

(a) Through shocks that affect relative factor prices and impact on different commodities differently in line with their factor intensity - in this route the sign on the RCA term will be ambiguous varying with the nature of the price shock.

(b) Through a catch-up effect, so that where a competitor has low initial market shares it will be easier for them to gain in activities in which an

\footnotetext{
${ }^{4}$ This variable is related directly to the more conventional measure of competitiveness - the change in the revealed comparative advantage ratio. When the revealed comparative advantage ratio is defined (as below) as the relative ratio for a country in a particular market with China as a comparator, then ranking by our competitiveness measure will be identical to ranking by the change in the ratio.

${ }^{5}$ Relative revealed comparative advantage is defined as $\mathrm{RCA}=\left(X_{i j} / X_{t j}\right) /\left(X_{i k} / X_{t k}\right)$ where $X$ refers to export value, $t$ stands for total exports and $k$ is the comparator economy.

${ }^{6}$ Because we work at the disaggregate four-digit level the model is very constrained by data availability, and because of our highly disaggregate focus we do not have access to conventional measures that can explain changes in export market shares, such as unit labour cost or R\&D activity. Hence the use of the initial RCA variable to capture the individual characteristics of products. Analyses that utilise such variables must normally work at much higher levels of aggregation; for example, Carlin et al. (2001) for OECD countries focus on changes in market share at the level of 12 divisions of manufacturing.
} 
economy is highly specialised - in this route the expectation is that the RCA term will always be negatively related to change in competitiveness. This will be most relevant for very large and very small observations for RCA since, if catch-up is a universal pattern across all observations, ultimately it will result in homogeneity in export structure across countries, which is implausible.

Our theoretical model focuses on the first of these two routes, although it must be acknowledged that empirically, whenever a negative relation between the competitiveness and RCA variables is found, we will be unable to distinguish between which of these two mechanisms is at work.

As total trade covers a wide variety of product types to impose some pattern on the data we classify these by the nine product categories of Lall (2000). ${ }^{7}$ These can be interpreted as descriptive classifications of relatively homogeneous product categories. Our use of dummy variables reflecting these nine categories implies that there is broad homogeneity within each in terms of the response of different products to the explanatory variables. However, within these classifications we also attempt to capture the degree of technological sophistication by applying the sophistication index of Kwan (2002). The Kwan index is calculated at the four-digit level to capture the technological sophistication of a trade category. It is based on the assumption that the sophistication of a commodity can be approximated by the weighted average income per capita of its exporters with the weights determined by the share of each exporter in the US market. This index gives a unique value for each trade category. The expectation is that products based on assembly-type production will have a relatively low value of the index (as they are assembled in low-wage economies) and that products with higher local value-added will have a higher value of the index. If it is the case that ASEAN's market position is protected by a technological advantage within a broad trade category, we expect that the sign on the Kwan index would be positive.

In the regression model we attempt to test for the impact of specialisation and technological sophistication on competitiveness, whilst controlling for changes in tastes as between the two markets. ${ }^{8}$

\footnotetext{
7 The Lall classification is a widely cited approach, which utilises earlier classifications and data on R\&D expenditure, to classify trade categories by factor and technology characteristics. Like any such broad approach it is subject to reservations concerning the homogeneity of the categories. It groups products at the three-digit SITC level into the following nine main classifications - primary products, resource-based manufactures, low technology manufactures (split between textiles, garments and footwear, and others), medium technology manufactures (split between engineering, automotive products and process products) and high technology (split between electronics and electricals and others).

${ }^{8}$ The full regression model takes the form:
}

$$
\begin{aligned}
\mathrm{COMP}_{i t}= & \left(\alpha_{1}+\ldots+\alpha_{9}\right) \mathrm{DVS}_{i t}+\left(\beta_{1}+\ldots+\beta_{9}\right) \mathrm{DVD}_{i t}+\varphi \mathrm{AD}_{t} \\
& +\left(\gamma_{1}+\ldots+\gamma_{9}+\eta \mathrm{AD}_{t}\right) \log \left(\mathrm{RCA}_{i}\right)+\left(\delta_{1}+\ldots+\delta_{9}\right) \mathrm{TECH}_{i}+\varepsilon_{i t}
\end{aligned}
$$




\section{c. Regression Results}

We conduct the analysis across 690 four-digit SITC categories, first for the ASEAN 5 and then for each economy individually. The full regression results are available in Weiss and Gao (2002) and here we highlight only the key findings. The broad results strongly support the view that the main ASEAN economies have been exposed to increasing competition from China in both the US and Japanese markets. Further, their reduced competitiveness in terms of changes in market share vis-à-vis China appears to be related systematically to particular product categories with losses greater in the areas within these categories, where the ASEAN economies are most highly specialised relative to China. The pattern of loss of competitiveness also shows a broad similarity for both the US and Japanese markets.

Tables 2 and 3 summarise the situation for different ASEAN 5 economies in the US and Japanese markets respectively.

Significantly, there is evidence of increased competition from China at both the relatively labour-intensive and the relatively high-technology end of the product scale, although within a given trade category technological sophistication appears generally to offer some protection for ASEAN exporters. This latter effect is found in different product categories for different countries and appears to be most uniform for engineering products in the US. The only product category for which there is no evidence of systematic loss of competitiveness is automobile products, which is both small in value and for which we have the smallest number of observations in our analysis. In no product category is there any evidence of systematic gains relative to China, although for a few countries

where COMP is the competitiveness term relative to China as a proportion of exports, TECH is a measure of technological characteristics of individual products (at the SITC four-digit level), and RCA is the relative revealed comparative advantage measure for the same product at the four-digit SITC level.

To distinguish products where there have been demand-side shocks, defined as those where the sign on the competitiveness change differs between the US and Japanese markets, we introduce two further dummies. A demand shock dummy (DVD) takes a value of unity when the sign on the competitiveness term between the two markets differs and zero when the sign on the competitiveness term is the same. The supply shock dummy (DVS) takes a value of unity when the sign in the two markets is the same and zero when it is opposite. The constant $\alpha$ DVS refers to the interaction term between a dummy for each of these nine groupings and DVS. It can be interpreted as picking up the impact of general supply shocks, unrelated to either factor intensity or technological sophistication, plus generally favourable demand factors that are uniform between the two markets. The constant $\beta$ DVD refers to the interaction term between a dummy for each of these nine groupings and DVD. It should pick up the impact of changes in taste that vary between the two markets. In addition, the terms $\gamma$ TECH and $\delta$ RCA are interaction terms between the TECH and RCA variables and the dummies for the nine product groupings. We use a log form for $\delta$ RCA. In addition, to allow for the possible disruptions brought about by the Asian financial crisis and its aftermath, we introduce further annual dummies (AD) that take a value of unity for 1997-1998, 1998-1999 and 1999-2000. 
TABLE 2

Regression Summary for the US Market

\begin{tabular}{|c|c|c|c|c|c|c|}
\hline Sector/Country & ASEAN & Indonesia & Philippines & Malaysia & Thailand & Singapore \\
\hline Primary product & & $*, \mathrm{~K}-$ & $*$ & $*$ & & $*$ \\
\hline $\begin{array}{r}\text { Resource-based } \\
\text { manufactures }\end{array}$ & $*$ & $*$ & $*$ & $*$ & $*$ & $*, \mathrm{~K}+$ \\
\hline $\begin{array}{l}\text { Textiles, garments } \\
\text { and footwear }\end{array}$ & $\mathrm{K}-$ & $*$ & * & * & & * \\
\hline \multicolumn{7}{|l|}{ Automotive } \\
\hline Engineering & $*, \mathrm{~K}+$ & $*, \mathrm{~K}+$ & $*, \mathrm{~K}+$ & $*, \mathrm{~K}+$ & $*$ & $*, \mathrm{~K}+$ \\
\hline $\begin{array}{l}\text { Electronic and } \\
\text { electrical }\end{array}$ & $*$ & $*, \mathrm{~K}+$ & $*, \mathrm{~K}+$ & $*$ & & $*$ \\
\hline Other low-tech & $*, \mathrm{~K}+$ & $*$ & $*$ & $*, \mathrm{~K}+$ & $*, \mathrm{~K}+$ & $*, \mathrm{~K}+$ \\
\hline Process & & $*$ & & & & $*$ \\
\hline Other high-tech & $*$ & & $*$ & * & $*$ & $*$ \\
\hline $\begin{array}{l}\text { Number of categories } \\
\text { with significant loss }\end{array}$ & 5 & 7 & 7 & 7 & 4 & 8 \\
\hline
\end{tabular}

Notes:

* Indicates competitiveness significantly related to RCA with negative sign.

$\mathrm{K}+$ indicates Kwan index significant with positive sign,

$\mathrm{K}$ - indicates Kwan index significant with negative sign.

${ }^{a}$ Significant loss refers to categories where competitiveness is significantly related to RCA with a negative sign.

TABLE 3

Regression Summary for the Japanese Market

\begin{tabular}{|c|c|c|c|c|c|c|}
\hline Sector/Country & ASEAN & Indonesia & Philippines & Malaysia & Thailand & Singapore \\
\hline Primary product & $*$ & * & & $*$ & $*$ & $*$ \\
\hline $\begin{array}{r}\text { Resource-based } \\
\text { manufactures }\end{array}$ & $*, \mathrm{~K}+$ & $*, \mathrm{~K}+$ & & & $*$ & $*$ \\
\hline $\begin{array}{l}\text { Textiles, garments } \\
\text { and footwear }\end{array}$ & & * & * & & * & \\
\hline Automotive & & & & & & \\
\hline Engineering & * & $*$ & $*, \mathrm{~K}+$ & * & $*$ & $*, \mathrm{~K}+$ \\
\hline $\begin{array}{l}\text { Electronic and } \\
\text { electrical }\end{array}$ & $*$ & $*$ & $*$ & $*, \mathrm{~K}+$ & $*$ & $*$ \\
\hline Other low-tech & $*, \mathrm{~K}+$ & $*, \mathrm{~K}+$ & * & & $*, \mathrm{~K}+$ & $*, \mathrm{~K}+$ \\
\hline Process & * & $*$ & * & & * & $*$ \\
\hline Other high-tech & $*, \mathrm{~K}+$ & $*$ & * & $*, \mathrm{~K}+$ & * & * \\
\hline $\begin{array}{l}\text { Number of categories } \\
\text { with significant loss }\end{array}$ & 7 & 8 & 6 & 4 & 8 & 7 \\
\hline
\end{tabular}

Notes:

* Indicates competitiveness significantly related to RCA with negative sign.

$\mathrm{K}+$ indicates Kwan index significant with positive sign,

$\mathrm{K}$ - indicates Kwan index significant with negative sign.

${ }^{a}$ Significant loss refers to categories where competitiveness is significantly related to RCA with a negative sign. 
and categories we find a significant cross-over rate for the RCA variable which implies that at lower levels of specialisation there is a gain of competitiveness vis-à-vis China, whilst there are losses at higher levels. ${ }^{9}$

For the large categories of electronics and electricals and engineering (which combined are two-thirds of ASEAN exports in the US and two-fifths in Japan) there is a consistent pattern of loss of competitiveness, which is stronger in more specialised products, and which holds for all countries in both markets. For the other important categories of primary products, resource-based manufactures and textiles and garments, all countries show significant losses in either the US or Japan and in a majority of cases for these categories, countries show a significant loss in both markets. Again this is always significantly related to the degree of specialisation..$^{10}$ It must be stressed that loss of competitiveness as defined here refers to loss of market share relative to China. This does not necessarily convert into an absolute decline in exports. Absolute export declines for ASEAN are found for primary products and engineering in the US and for primary products, resource-based manufactures, and textiles, garments and footwear in Japan. Hence much of the erosion of market share is in categories whose sales from ASEAN are continuing to expand, principally the very large category of electronics and electrical goods. Here losses of market share are in the product lines where ASEAN is most specialised eroding established market positions. This implies the need to consider some future restructuring, but it is not an immediate crisis in terms of declining absolute values of export sales. Also some of the gains by China in this category are misleading in that they relate to the export of assembled parts and components, some of which will have been exported to China by ASEAN producers. This emerging regional division of labour over 1995-2000 had only a modest impact in compensating ASEAN economies for their loss of export market share, with (on aggregate) a net export gain in sales to China of less than 20 per cent of the combined value of the loss of market share in the US and Japan estimated by Weiss and Gao (2002) over the period of study. In terms of parts and components exports to China it appears that Malaysia and Thailand are the economies where the strongest signs of this compensating effect have begun to emerge.

\footnotetext{
9 These crossover RCAs require the sign on the constant and the RCA variable to differ and for all three terms - the constant for each product category, the RCA and the Kwan index - to be significant.

${ }^{10}$ Weiss and Gao (2002) hypothesise from their simple model that the link between greater specialisation in ASEAN relative to China and loss of market share is due to shifts in the relative capital rental-wage ratios that are favourable to China and hence unfavourable to ASEAN. Increased domestic savings or rising FDI inflows to China, which increase the supply of capital and lower the capital rental-wage ratio, are simple candidates for a general explanation. Naturally, more detailed industry-specific effects as well as general catch-up trends, noted earlier, may also be at work, but our analysis does not allow us to capture these.
} 


\section{A NEW APPROACH TO EVALUATING COMPARATIVE ADVANTAGE}

An alternative perspective on ASEAN-China economic relations can be gleaned from analysis of bilateral trade flow data focusing on skilled and unskilled labour content as a means of elucidating the value-added hierarchy in trade across the region. Our perspective is that in a globalising economy in the long run, capital is mobile and wage differentials can only be sustained by productivity differences and thus the skill content of trade becomes an essential determinant of real comparative advantage. ${ }^{11}$ Our approach is to synthesise detailed trade flow data with domestic skill content information and impute trade in embodied labour services.

\section{a. Embodied Labour Service Trade}

To measure more effectively the skill content of trade, and use this for assessing national competitiveness we build upon an index developed initially by Balassa to study patterns of intra-industry trade. Formally, we can define the index of intra-industry competitiveness (IIC) as

$$
\mathrm{IIC}=(E-M) /(E+M) .
$$

where IIC ranges between -1 (100 per cent import oriented) and 1 (100 per cent export oriented) for any given sector $i$. This index is quite easy to calculate for even the most detailed customs lines. It can be done for one country's trade with the rest of the world, or within each of its bilateral relationships. As the level of disaggregation increases, the computed index move toward the $[-1,1]$ endpoints, but intra-industry trade (interior values) is an ever more persistent real-world phenomenon.

While the IIC index is of interest in itself, our goal is to extend it to capture 'qualitative' features of competitiveness, in this case skill content of value-added. Clearly, much of the spirit of competition in East Asia is focused on migrating up the value-added 'ladder'. This means countries are striving to be export oriented in higher wage-intensive goods and import oriented in lower wage-intensive goods. To extend our analysis in this direction, detailed trade flow data were adjusted to capture differences in average skill content of embodied labour services. In particular, for country $k$ and sector $i$, we define:

$$
\lambda_{i}^{k}=\frac{\operatorname{LVA}(\text { Skilled })_{i}^{k}}{\operatorname{LVA}(\text { Unskilled })_{i}^{k}}
$$

${ }_{11}$ There are many examples of empirical trade analysis from a labour content perspective; see text van der Mensbrugghe (1998), Lee and Roland-Holst (1994 and 1995) and Collado et al. (1995). 
where LVA denotes labour value-added for each sector and country. This measure indicates the relative skill content, per unit of output, and is independent of exchange rates.

The next step is to use this information to adjust trade flows for each country and commodity category. At this level of detail, we define the traditional competitiveness measure as:

$$
\mathrm{IIC}_{i}^{k m}=\frac{E_{i}^{k m}-E_{i}^{m k}}{E_{i}^{k m}+E_{i}^{m k}}
$$

where the variable $E_{i}^{k m}$ denotes exports of sector $i$ commodities from country $k$ to country $m$. This more detailed index can then be recast in terms of skills with the Embodied Labour Service Trade (ELT) index, so that:

$$
\operatorname{ELT}_{i}^{k m}=\frac{\lambda_{i}^{k} E_{i}^{k m}-\lambda_{i}^{m} E_{i}^{m k}}{\lambda_{i}^{k} E_{i}^{k m}+\lambda_{i}^{m} E_{i}^{m k}}
$$

which also varies in the interval $[-1,1]$ and denotes the relative export or import orientation of embodied labour service trade.

\section{b. Empirical Estimates}

Using the relatively simple derivations noted above, we now present a spectrum of results on patterns of competitiveness in East Asia calculated using twodigit bilateral trade flows for 2000. ${ }^{12}$ Details are in Roland-Holst (2003). Trade categories are classified into three groups depending upon the calculated values of ELT and IIC, as defined above. Using the three equal segments of the closed interval $[-1,1]$, a category is treated as import dependent if the IIC or ELT is within the range -1 to -0.33 ; it is treated a trade neutral if the IIC or ELT is within the range -0.33 to 0.33 and export oriented if the IIC or ELT is within the range 0.33 to 1.0. From an analysis of data for 2000 using the IIC indicator Japan and the newly industrialised economies (NIEs) exhibit a high degree of trade specialisation,

\footnotetext{
${ }^{12}$ Indices of labour value added were obtained using country-specific input-output accounts from the Global Trade Analysis Project (GTAP). The main information resource of this project is a database that reconciles macroeconomic and input-output accounts from over 66 countries and regional aggregate economies into a single global data resource; see Hertel et al. (2000) or consult www.gtap.org for complete documentation. The labour data we use are derived from the valueadded accounts of GTAP, which are documented in detail in Chapter 18, Section D, of Dimaranan and McDougall (2002) and may also be consulted online; see www.gtap.agecon.purdue.edu/ resources/download/798.pdf. Labour was disaggregated from total employment using the ILO definitions of skilled and unskilled workers. The definition of professional and production workers is based on the ILO International Standard Classification of Occupations (ISCO); see ILO (2002). For the technical methods and detailed assumptions, see Tri and Tyers (1996).
} 
with strong export orientation. The NIE group (Korea and Taipei China) is the most export oriented (84 per cent of categories in IIC terms), while China, ASEAN, the US and the EU exhibit a higher degree of neutrality. Japan and the US have a relatively large percentage of import-dependent categories, as one might expect, while the EU appears to be relatively devoid of trade specialisation.

If we re-examine trade through the lens of embodied labour skill composition using the ELT measure, the results cast new light on trade hierarchy with respect to East and Southeast Asia. From this perspective, we find that, with respect to emergent Asian exporters, the skill-adjusted trade position of OECD economies is much stronger than simple trade flow data would suggest. Japan, for example, has 80 per cent of its skill-adjusted trade in export-oriented sectors, while the corresponding simple trade (IIC) percentage is only 63 per cent.

\section{c. Bilateral Trade}

With these aggregate comparisons in mind, we now turn to more detailed, bilateral trade conditions, particularly as they relate to ASEAN and China. Our results show more finely delineated patterns of regional comparative advantage. Trade classification is gauged both by share of the three different classifications (export-oriented, trade neutral and import-dependent) in trade value (trade-weighted percentages) and by number of categories in the three possible classifications (sector count). For the analysis of China's trade the results reveal that bilateral differences between IIC and ELT indices are very strong, with China apparently quite import-dependent in terms of skill intensity. While this is an important reminder about the emergent status of China's labour market, the qualitative uniformity of this result is striking. Even ASEAN exceeds China in the skill intensity of its bilateral exports, although the inclusion of Singapore in this group is essential to bear in mind here. Another salient feature of China's ELT results is that there is very little middle ground. China's skill-weighted trade is mainly strong export or strong import-oriented, without much neutrality. This results from a combination of features, including the fact that China appears to be exporting from the extremes of its labour force, either high- or low-skill labour content, while mid-skill labour is probably more concentrated in services and other non-tradables. Another reason for the skill dichotomy is probably China's continued reliance on imported capital goods and high technology.

Also it is worth noting the aggregation bias that appears when trade flows are consolidated across partners. Trade with all partners appears to be quite balanced, but we see that China's trade with individual partners is not only more specialised, but dichotomous in the way described above (mostly high and low skill). Of course it makes sense that aggregation across trade partners would reduce apparent specialisation, but variations across trading partners are quite important to the evolution of regional trading hierarchy. 
ASEAN generally exhibits significant differences between simple trade orientation and embodied skill orientation, but the direction of this difference varies with trading partners in interesting ways, indicating an intermediate position for ASEAN in the regional hierarchy of value-added. ${ }^{13}$ The good news for ASEAN, in one sense at least, is that it appears to be holding its own with respect to China, in terms of skill intensity, although again the inclusion of Singapore may bias the interpretation here. Our results indicate that, in 2000, in its trade with China ASEAN was 19 per cent more export-oriented on a skill-adjusted basis than its raw trade statistics would indicate. In trade with other partners, the patterns appear to be more intuitive. Both Japan and the US have much higher export advantages in terms of skill orientation in their trade with ASEAN.

\section{d. Recent Trends in International Competitiveness}

These results give a static picture of comparative advantage. While such results are thought-provoking, most observers of the economies under discussion are at least equally concerned about the underlying trends in regional specialisation and factor composition. For this reason, we generate the same information for an earlier year (1996) and report the results that indicate how trade and embodied labour value patterns may be shifting.

As before we classify trade into one of three groups both by share of the three different categories in trade value (trade-weighted percentages) and by numbers of sectors in the three possible categories (sector count). We then find, for example, the percentage of China's trade that is import-dependent by either the IIC or ELT measure. By comparing the results for 2000 and 1996 we obtain an estimate of changing trade structure and comparative advantage. For example, in Table 4 we show differences in the underlying IIC and ELT tercile percentages. For example, the element in row 1, column 1, indicates that, between 1996 and 2000, China's IIC import orientation fell by 17 percentage points, with all this activity moving to neutral orientation. By contrast, its skill-adjusted trade was 16 percentage points less import-oriented by 2000, but was 5 percentage points more export-oriented. Thus China has indeed migrated up the value-added ladder in terms of export orientation. Other columns give the changes in trade orientation of other countries. Obviously, the net result of these adjustments must be zero for each country. ${ }^{14}$

\footnotetext{
${ }^{13}$ For more extended background on ASEAN experience in this context, see Tan (1998).

${ }^{14}$ The per cent changes reported in Tables 4 to 6 do not directly measure changes in underlying trade balances or overseas market shares, which are the concern of our econometric analysis. What is being shown here is based on tercile movements for an index of (simple and skill weighted) trade orientation. Thus an entry of $(+1)$ implies a one percentage point increase in (simple or trade weighted), the tercile share of (respectively) import-dependent, neutral or export-oriented activity. However, in the case of IIC, movements in the three ranks are directly correlated with net trade $(E-M)$ and will agree in sign with this balance, but even this index is normalised by contemporaneous total trade.
} 
TABLE 4

Change in International Competitiveness, 1996-2000 (Percentage point differences)

\begin{tabular}{|c|c|c|c|c|c|c|c|c|c|c|c|c|c|c|}
\hline & \multicolumn{7}{|c|}{ Trade-weighted Percentages } & \multicolumn{7}{|c|}{ Percentages by Sector Count } \\
\hline & $\begin{array}{l}\text { l China } \\
\text {. }\end{array}$ & $\begin{array}{l}2 \\
\text { Japan }\end{array}$ & $\begin{array}{l}3 \\
\text { NIEs }\end{array}$ & $\begin{array}{l}4 \\
A S E A N\end{array}$ & $\begin{array}{l}5 \\
U S A\end{array}$ & $\begin{array}{l}6 \\
E U\end{array}$ & $\begin{array}{l}7 \\
\text { Total }\end{array}$ & $\begin{array}{l}8 \\
\text { China }\end{array}$ & $\begin{array}{l}9 \\
\text { Japan }\end{array}$ & $\begin{array}{l}10 \\
\text { NIEs }\end{array}$ & $\begin{array}{l}11 \\
\text { ASEAN }\end{array}$ & $\begin{array}{l}12 \\
\text { USA }\end{array}$ & $\begin{array}{l}13 \\
E U\end{array}$ & $\begin{array}{l}14 \\
\text { Total }\end{array}$ \\
\hline \multicolumn{15}{|l|}{ IIC } \\
\hline 1 Import & -17 & -21 & -17 & -27 & 9 & -1 & & -12 & -6 & -5 & -10 & 7 & 1 & \\
\hline 2 Neutral & 17 & -7 & -21 & 29 & 33 & 52 & & 5 & 5 & 3 & 8 & 3 & -2 & \\
\hline 5 Export & 0 & 28 & 38 & -2 & -42 & -51 & & 7 & 1 & 2 & 2 & -10 & 1 & \\
\hline \multicolumn{15}{|l|}{ ELT } \\
\hline 6 Import & -16 & -3 & -2 & -6 & 14 & 0 & & -20 & -8 & 0 & -1 & -7 & 2 & \\
\hline 7 Neutral & 11 & -1 & -4 & 6 & 15 & 3 & & -3 & 10 & -13 & -17 & -24 & -49 & \\
\hline 10 Export & 5 & 4 & 6 & 0 & -29 & -3 & & 23 & -2 & 13 & 18 & 31 & 47 & \\
\hline
\end{tabular}


In addition to China, there are a variety of other interesting trends in the aggregate trade data. All the East Asian economies, for example, have reduced the percentage of their activities that are import-dependent, but this has different consequences for different countries. Japan and the NIE, for example, experience strong accompanying shifts toward export orientation, with 28 and 38 percentage point net increases in this category, respectively. In terms of skill-adjusted trade, however, Japan and NIEs experience much less structural shift, but there is still a net shift from import to export orientation. At the same time, ASEAN has seen its trade shift toward neutrality from both import and export orientation.

Trends for western OECD economies are comparable in simple trade orientation but differ markedly when account is taken of skill content. Both the US and EU see big declines in the net percentage of export-oriented sectors over the 1996-2000 period (-42 and -51 percentage points, respectively). For the US, this translates into increased neutrality and import orientation, while for the EU neutrality alone increases. When account is taken of skill content, however, the US still loses 42 percentage points of its trade-weighted export-oriented activities, with half of this amount now represented by import dependence. For the EU, skill adjustment erases most of commodity trade shift, and only a small move toward neutrality is apparent.

Tables 5 and 6 show the same results for bilateral trade. Table 5 presents results for China for trade with each of the countries and country groups already considered. Columns show the composition of bilateral trade with different partners. In Table 5, for example, columns 1-6 and 8-13 correspond to bilateral trade between China and the column-heading partner, while columns 7 and 14 apply to China's trade with all partners. As in Table 4, percentage point changes in trade orientation are shown. Entries for China itself are zero.

For China the aggregate trade results (columns 7 and 14) indicate a net shift out of import dependence and even, in terms of skill content, gains in export specialisation. While aggregation across trading partners may not have introduced serious bias, the detailed results indicate very different bilateral adjustments, and these can be expected to bear significantly on the political economy of trade and other negotiations. In trade with Japan, China has significantly increased the percentage of its import-dependent domestic activities. This trend is consistent with anecdotal evidence on flows of capital and advanced intermediate goods. When looking at these adjustments from a skill content perspective, one might expect even greater percentage changes. The opposite occurs, however, probably because Japanese capital goods are moving into Chinese sectors with much higher than average skill content. The trend established with Japan is mirrored in trade with NIEs, although the percentage changes are even greater because of the NIEs' higher specialisation.

China's trade with ASEAN appears to be evolving somewhat differently (columns 4 and 11). From the raw trade data, one might infer that China's export 
TABLE 5

Change in International Competitiveness, 1996-2000: China Bilateral Trade (Percentage point differences)

\begin{tabular}{|c|c|c|c|c|c|c|c|c|c|c|c|c|c|c|}
\hline & \multicolumn{7}{|c|}{ Trade-weighted Percentages } & \multicolumn{7}{|c|}{ Percentages by Sector Count } \\
\hline & $\begin{array}{l}\text { l China } \\
\text { Con }\end{array}$ & $\begin{array}{l}2 \\
\text { Japan }\end{array}$ & $\begin{array}{l}3 \\
\text { NIEs }\end{array}$ & $\begin{array}{l}4 \\
A S E A N\end{array}$ & $\begin{array}{l}5 \\
U S A\end{array}$ & $\begin{array}{l}6 \\
E U\end{array}$ & $\begin{array}{l}7 \\
\text { Total }\end{array}$ & $\begin{array}{l}8 \\
\text { China }\end{array}$ & $\begin{array}{l}9 \\
\text { Japan }\end{array}$ & $\begin{array}{l}10 \\
\text { NIEs }\end{array}$ & $\begin{array}{l}11 \\
A S E A N\end{array}$ & $\begin{array}{l}12 \\
U S A\end{array}$ & $\begin{array}{l}13 \\
E U\end{array}$ & $\begin{array}{l}14 \\
\text { Total }\end{array}$ \\
\hline \multicolumn{15}{|l|}{ IIC } \\
\hline 1 Import & 0 & 18 & 30 & 2 & -40 & -42 & -17 & 0 & -6 & -6 & -4 & -10 & -8 & -12 \\
\hline 2 Neutral & 0 & -10 & -18 & 26 & -4 & 35 & 17 & 0 & 7 & 7 & 2 & -1 & 8 & 5 \\
\hline 5 Export & 0 & -8 & -12 & -28 & 44 & 7 & 0 & 0 & -1 & -1 & 2 & 11 & 0 & 7 \\
\hline \multicolumn{15}{|l|}{ ELT } \\
\hline 6 Import & 0 & 2 & 3 & 22 & -37 & 2 & -16 & 0 & -44 & -42 & -19 & -2 & -11 & -20 \\
\hline 7 Neutral & 0 & -1 & -4 & -18 & 32 & -1 & 11 & 0 & 16 & 25 & -17 & -26 & -9 & -3 \\
\hline 10 Export & 0 & -1 & 1 & -4 & 5 & -1 & 5 & 0 & 30 & 17 & 36 & 28 & 20 & 23 \\
\hline
\end{tabular}


TABLE 6

Change in International Competitiveness, 1996-2000: ASEAN Bilateral Trade (Percentage point differences)

\begin{tabular}{|c|c|c|c|c|c|c|c|c|c|c|c|c|c|c|}
\hline & \multicolumn{7}{|c|}{ Trade-weighted Percentages } & \multicolumn{7}{|c|}{ Percentages by Sector Count } \\
\hline & $\begin{array}{l}1 \\
\text { China }\end{array}$ & $\begin{array}{l}2 \\
\text { Japan }\end{array}$ & $\begin{array}{l}3 \\
\text { NIEs }\end{array}$ & $\begin{array}{l}4 \\
A S E A N\end{array}$ & $\begin{array}{l}5 \\
U S A\end{array}$ & $\begin{array}{l}6 \\
E U\end{array}$ & $\begin{array}{l}7 \\
\text { Total }\end{array}$ & $\begin{array}{l}8 \\
\text { China }\end{array}$ & $\begin{array}{l}9 \\
\text { Japan }\end{array}$ & $\begin{array}{l}10 \\
\text { NIEs }\end{array}$ & $\begin{array}{l}11 \\
A S E A N\end{array}$ & $\begin{array}{l}12 \\
U S A\end{array}$ & $\begin{array}{l}13 \\
E U\end{array}$ & $\begin{array}{l}14 \\
\text { Total }\end{array}$ \\
\hline \multicolumn{15}{|l|}{ IIC } \\
\hline 1 Import & -27 & -28 & -7 & 0 & -57 & -50 & -27 & 2 & -14 & -8 & 0 & -20 & -8 & -10 \\
\hline 2 Neutral & 24 & 38 & 3 & 0 & 31 & 28 & 29 & 2 & 13 & 8 & 0 & 12 & 4 & 8 \\
\hline 5 Export & 3 & -10 & 4 & 0 & 26 & 22 & -2 & -4 & 1 & 0 & 0 & 8 & 4 & 2 \\
\hline \multicolumn{15}{|l|}{ ELT } \\
\hline 6 Import & -3 & 1 & -15 & 0 & -5 & -57 & -6 & 14 & -48 & -30 & 0 & 16 & 15 & -1 \\
\hline 7 Neutral & -13 & -1 & 15 & 0 & -1 & 54 & 6 & -31 & 16 & 17 & 0 & -40 & -35 & -17 \\
\hline 10 Export & 16 & -1 & 0 & 0 & 6 & 3 & 1 & 17 & 32 & 13 & 0 & 24 & 20 & 18 \\
\hline
\end{tabular}


advantage has deteriorated, with a 28 percentage point change in export-oriented activities, which shift principally to the trade neutral category. Taking account of embodied skills, however, a different adjustment process is revealed. Here there is less reduction in the export-oriented category, but a strong shift from neutral activities to import-dependent ones. In this way, it appears that skill-adjusted bilateral trade is becoming more polarised between these two partners. Trade with the western OECD economies appears consistent with conventional intuition, with China emerging as a strong export competitor in simple trade orientation. Taking account of skill content, however, these industrialised partners concede very little of their export advantage.

In summary the aggregate trade results for China do not indicate that significant skill upgrading of its comparative advantage has taken place over the period 1996-2000. In this sense, China's much acclaimed skilled job growth does not appear to be shifting it sharply toward higher value-added competitiveness. Having said this, it is noteworthy that skill-oriented import reliance has declined significantly, with the economy moving closer to neutrality. The two primary explanations for this are probably higher technology import substitution and basic economic diversification accompanying the development process.

ASEAN's bilateral trade composition is shown in Table 6. Here ASEAN appears to have seen improved conditions of international competitiveness, in terms of both trade and skill orientation, over the 1996-2000 interval, despite the losses in market share to China examined earlier. While the percentage of exportoriented activity declined by 2 percentage points in aggregate, this figure expanded sharply with respect to important trading partners, like the US and the EU, and grew modestly with China and the NIEs. More striking was the decline in overall import dependence, ranging from a low of -7 percentage points with the NIEs to -57 percentage points with the US. This trend and the companion shift toward trade neutrality were probably due to a combination of three factors: growth of intra-ASEAN trade, the impact of the Asian financial crisis and domestic economic diversification.

\section{CONCLUSIONS}

When considering all the excitement among China observers, it is important to emphasise the difference between aggregate growth and compositional effects. Certainly, this economy's growth has been spectacular as evidenced in the first part of this paper, but the optimism about rapid migration up the value-added ladder apparently needs to be tempered. Chinese skilled employment has grown much faster than is traditional for developing countries, and certainly this will improve the distributional properties of domestic income growth over the course of China's longer-term expansion. This admirable rate of absolute job growth is 
probably relatively balanced, however, especially in light of the obvious fact that the most elastic supply of domestic labour is not in the higher skill categories. In particular, China's ability to shift real comparative advantage to higher skill levels also depends on superior growth in the share of this employment, and convincing evidence in this area is harder to establish. In addition, China's burgeoning demand for imports of all kinds, and those of higher skill content in particular, will influence this outcome.

In terms of ASEAN, the emergence of China has increased uncertainty about the evolution of regional activity. Many observers are concerned that in the short and medium term direct and indirect competition may lead to painful domestic structural adjustments. The lessons of recent history, as distilled in the present research, indicate that regional patterns of comparative advantage are fairly robust, but that many specific areas of trade friction and structural adjustment can be expected to arise in the short and medium term.

In particular, detailed econometric analysis strongly supports the view that the main ASEAN economies have been exposed to increasing competition from China in both the US and Japanese markets. Further, the reduced competitiveness, in terms of changes in market share vis-à-vis China, appears to be related systematically to particular product categories with losses greater in the areas within these categories, where the ASEAN economies are most highly specialised relative to China.

From an alternative perspective, however, we examine detailed trade patterns with more descriptive tools, calculating indices of simple trade orientation and trade orientation adjusted for skilled labour content. The emergence of new competition in regional commodity trade is undeniable, but the de facto regional hierarchy of value-added in East Asia has not been substantially altered. Indeed, the most skill-intensive exporters, Japan and the NIEs, have actually intensified their 'skill specialisation' over the period 1996-2000. In a post-WTO era where mercantilism is untenable, these results point to a neo-mercantilism of valueadded capture, where economies increase both imports and exports, but strive to maximise the skill margin between the two. ${ }^{15}$

Generally speaking, our results indicate that the potential for regional trade to accommodate new suppliers is considerable, particularly in the longer term when Chinese absorption can be expected to increase and dominate regional demand. These results are of considerable policy relevance in their own right, since they may help counter trade rivalry and protectionist sentiment that can exploit a weaker basis of evidence on actual trade experience. Having said this, however, we also find specific indications that export competition has stiffened sharply as a result of China's emergence. A combination of careful policy coordination and

${ }_{15}$ Warnings about the sustainability of this approach are many (for example, OECD, 1999, and UNCTAD, 1999), but the temptation is great. 
sustained aggregate economic growth are the best opportunity for governments and enterprises to realise the immense economic potential of this region and its people.

\section{REFERENCES}

Asia-Pacific Economic Cooperation (APEC) (1997), The Impact of Trade Liberalization in APEC (Singapore: APEC Secretariat).

Carlin, W., A. Glyn and J. van Reenen (2001), 'Export Market Performance of OECD Countries: An Empirical Assessment of Competitiveness', Economic Journal, 111, 128-62.

Collado, J. C., D. Roland-Holst and D. van der Mensbrugghe (1995), 'Latin America Employment Prospects in a More Liberal Trading Environment', in D. Turnham, C. Foy and G. Larrain (eds.), Social Tensions, Job Creation and Economic Policy in Latin America (OECD, Paris).

Dimaranan, B. V. and R. A. McDougall (eds.) (2002), Global Trade, Assistance, and Production: The GTAP 5 Database (Centre for Global Trade Analysis, Purdue University).

Hertel, T. W. (ed.) (2000), Global Trade Analysis: Modeling and Applications (Cambridge University Press, New York).

ILO (2002), Yearbook of Labor Statistics (International Labour Organization, Geneva).

Kwan, C. (2002), 'The Rise of China and Asia's Flying Geese Pattern of Industrial Development: An Empirical Analysis Based on US Import Statistics' (mimeo, Research Institute of Economy, Trade and Industry, Tokyo).

Lall, S. (2000), 'The Technology Structure and Performance of Developing Country Manufactured Exports, 1985-98', Oxford Development Studies, 28, 3, 337-69.

Lee, H. and D. Roland-Holst (1994), 'Shifting Comparative Advantage and the Employment Effects of US-Japan Trade', The World Economy, 17, 3, 323-45.

Lee, H. and D. Roland-Holst (1995), 'Trade Liberalization and Employment Linkages in the Pacific Basin', The Developing Economies, 33, 155-84.

OECD (1999), 'Open Markets Matter: The Benefits of Trade and Investment Liberalization', Policy Brief (Paris, October).

Richardson, J. (1971), 'Constant-Market-Shares Analysis of Export Growth', Journal of International Economics, 1, 2, 227-39.

Roland-Holst, D. (2002), 'An Overview of PRC's Emergence and East Asian Trade Patterns to 2020', Research Paper No. 44 (October, Asian Development Bank Institute, Tokyo, at www.adbi.org).

Roland-Holst, D. (2003), 'East Asian Patterns of Comparative Advantage' (mimeo, Asian Development Bank Institute, Tokyo, July, available at www.adbi.org).

Tan, K. Y. (1998), 'Regionalism in the Pacific Basin: Strategic Interest of ASEAN in APEC', in H. Lee and D. Roland-Holst (eds.), Economic Development and Cooperation in the Pacific Basin: Trade, Investment, and Environmental Issues (Cambridge: Cambridge University Press).

Tri, T. V. and R. Tyers (1996), 'Splitting Labor by Occupation in GTAP: Source and Assumptions' (mimeo, Australian National University).

United Nations Conference on Trade and Development (UNCTAD) (1999), A Positive Agenda for Developing Countries: Issues for Future Trade Negotiations (Geneva: United Nations).

van der Mensbrugghe, D. (1998), 'Trade, Employment and Wages: What Impact from 20 More Years of Rapid Asian Growth?', in C. Foy, F. Harrigan and D. O'Connor (eds.), The Future of Asia in the World Economy (OECD, Paris).

Weiss, J. and S. Gao (2002), 'China's Export Threat to ASEAN' (mimeo, Asian Development Bank Institute, Tokyo, October, available at www.adbi.org). 